\title{
Traditional Healing Practices and Holistic Health: The Implication for Christian Families in South West Region of Nigeria
}

\author{
Maria Natalia Ajayi, Gerisho Kirika, Johnson Mavole \\ Department of Religious Studies, Catholic University of Eastern Africa, Nairobi, Kenya
}

Email address:

natlyayo@yahoo.com (M. N. Ajayi)

\section{To cite this article:}

Maria Natalia Ajayi, Gerisho Kirika, Johnson Mavole. Traditional Healing Practices and Holistic Health: The Implication for Christian Families in South West Region of Nigeria. Journal of Family Medicine and Health Care. Vol. 5, No. 4, 2019, pp. 50-58.

doi: $10.11648 /$ j.jfmhc.20190504.13

Received: August 24, 2019; Accepted: September 26, 2019; Published: October 14, 2019

\begin{abstract}
The Christian family is considered as the first and basic expression of man's social nature. The family is also the smallest social unit and a community of persons, where love and affection are demonstrated in a genuine way. In this community of persons, two partners stay together and accept each other. They give themselves in love as they profess their faith during the sacramental rite of marriage. Thus, because of the significance and the vital role the family plays in the entire community and in the society, there is the utmost need to safeguard the interest of the family, especially when religion and health issues are involved. If the family is healthy, its members will be able to worship God in truth and in serenity of hearts. The society too will remain cohesive. Hence, it is important to understand the role of cultural beliefs and how they affect the individuals in the family in order to promote the stable and functional families that make up society. Therefore, this paper aims to discuss the influence of traditional healing practices Ifa (divination), rituals and sacrifices on holistic health among the Christian families in South-West Region of Nigeria. The goal is to discover different ways to help each family member gain the right knowledge about cultural beliefs and practices in order to achieve holistic health.
\end{abstract}

Keywords: Christian Family, Ifa (Divination), Rituals, Sacrifices, Holistic Health and Nigeria

\section{Introduction}

Among patients who seek health-care services and those who declare themselves not to be religious, there are often those who recognize themselves as spiritual to some extent [1]. This spirituality is often explained by the fact that they are people of religious beliefs and practices which influence their behaviour from time to time. These beliefs are usually born from a culture together with its practices. Since culture acts as a lens the perception and interpretation of the world should be done with cultural lenses [2]. Culture is important because it helps to define and interpret behavior and the meaning of disease, health and healing. The concept of holistic medicine suggests that it is important when patients are being cared for to consider their cultural views. This is because both health-care and illness are connected with culture and individuals' perceptions of the world. Therefore, for a better understanding of the meaning of sickness or the absence of health in an individual, we adopt the definition of the Oxford Dictionary which describes sickness, disease or illness as a disordered or incorrectly functioning organ within the body. Specifically, it means an organ that has specific effect on a particular body part and not necessary a physical injury directly as the outcome. This is an unhealthy condition of body or mind in a particular person makes one to seek for health at all cost.

The human person (male \& female) always desires health. It is only when one is healthy that one can be said to be happy either with self, with the other or with God. The one seeking holistic health must be considered from different angles including his or her cultural background. However, culture embeds the substratum of religion while taking into consideration religion and spirituality [3], while Rohricht, et al., (2009), lament that "religiosity was negatively associated with negative pathological symptoms". On the other hand, "personal devotion" had positive correlation with health 
related results, which is not the case in institutional religion [4]. This affirmation of positive relationship on religious people is an outcome of systematic studies of religion in which religious people in the setting of medicine compiled a documentation of high proportion of patients who depend on religious practices and beliefs in order to come up with health solutions.

In simple terms, this religiosity of the human being identifies a person's desire to be at peace with the Transcendent. The followers of religion are able to sustain a lifestyle and perform practices that are healthy in their lives [5]. Man and woman in search of answers to the problems they encounter engage themselves in the practice of religion. Religion exercised in beliefs and practices, and in the context of this paper (traditional healing practices) must not prevent one from attaining health, rather it is to be treated in a delicate manner so that its effects on health do not become a hindrance to the solution of health problems. This is the reason why religion becomes a necessary tool in providing answers to the question of how does traditional healing practices affect holist health in a Christian family. Religion becomes a system to facilitate support and healing for the ills of body and soul. In doing this, the human person should be taken as a whole, that is, soul, body and mind. This is the only way to advance healing in a holistic manner. Many people participate in this mission of helping an individual to attain health: parents, friends, relatives, teachers, medical practitioners, psychologists, counsellors, and especially religious health care-givers. To restore health holistically to every person will require the collective responsibility of all health care-givers while making use of everything useful from the environment. This is because every community is not just a place where human beings dwell. "The African community comprises of plants, animals, human beings, the spirit and the ancestors". [6]

In addressing this topic, attention will be focused on the effects of two traditional healing practices in the South West Region of Nigeria. These practices are, Ifa, which is divination, and the rituals and sacrifices used to restore health. The reason to investigate these practices is to achieve a better understanding of whether these healing practices among the Yoruba have had any influence on Christian families especially in their quest for healing. From the research done among the Christians families in the South West Region of Nigeria, the results of the findings will be presented to show the reader that cultural beliefs can affect religious people from time to time. The impact of the effects on holistic health needs to be attended to. The paper shall conclude by giving some recommendations on how best to attain holistic health amidst the influence of cultural beliefs especially when it affects the health of the human person. In the context of this paper, South West Region of Nigeria will also be referred to as Yoruba Land.

\section{Background of the Study}

The people of South-West Region of Nigeria (Yoruba) have strong attachment to their traditional beliefs and practices. When a person is sick in the family and has visited the hospital for health-care services, or the church, and there seems to be a delay in the healing process, there is always possibility of solving the problem by following the traditional way, because the cause of the problem has not been diagnosed easily, (e je ki ate se ile bo). This saying means, "let us solve this problem through the traditional way". It expresses a belief, which leads some Yoruba Christians to visit the traditional healers, diviners and sometimes woman goddesses. For the Yoruba, even those who are Christians, believe that through the consultation with Ifa [which means divination and with rituals and sacrifices], all problems will be solved.

\subsection{Statement of the Problem}

There seems to be a shallow understanding of enculturation and inculturation of the Yoruba traditional healing process and its implementation among the Christians in regard to their faith. Again, there seems to be lack of patience when any member of the family is experiencing challenges like sickness, misfortune, the lack of a job, or bad dreams. It would seem that the Yoruba believe that traditional mystical power is responsible for every misfortune, suffering and sickness that is beyond human understanding. For this reason, they seek solutions through the traditional way. The question is whether every sickness is caused by a mystical power and does one has to visit an Ifa priest before the problem is solved? What if the sickness is an emotional, or psychological, or is caused by carelessness or laziness? Can the traditional way of healing solve the problem of illness? Again, can the people justify their trust in the Yoruba traditional healing process as being holistic? Many people believe that to solve the problem of sickness in the family, the Yoruba traditional healing practices must be used as well.

Inculturation is about Christ informing all cultures. Yoruba culture, especially the healing practices must be evaluated in the light of Christ. In view of this, the use of traditional healing practices among the Yoruba need proper evaluation in the light of the Gospels. This implies that, the healing practices in Yoruba culture, for example, the use of herbs and plants for curing diseases that do not contradicts the healing of Jesus in the bible need not to be condemned. But if some practices are not in conformity with Jesus' teaching, then they are to be condemned. The Christians must move away from anything that is contrary to the teachings of Jesus Christ who is the great healer of mankind.

Hence, this study seeks for a better understanding of traditional healing practices among the Yoruba. A proper investigation of traditional healing processes that are not contrary to Christianity might need to address the progress of inculturation in the Church. If this is not done properly, the Christian teaching on health might be guilty of neglecting the African cultural, spiritual and ideal values, thereby leaving the contemporary health challenges un-addressed. 


\subsection{Justification of the Study}

Christians, in general, are the key beneficiaries of these findings, especially in the South-West Region of Nigeria, because of their need to be detached completely from the mentality of thinking that someone with mystical power is always the cause of their family problems. They believe a solution must be sought in the traditional way by visiting the traditional healers because these are more effective than the spiritual healers in the Churches. Sometimes, this mentality prevents many Christians from enjoying good health. This evidence of lack of faith in God who is the supreme healer calls for reflection.

The cultural values handed on to the Yoruba by their forefathers in the traditional healing process seem not to have been studied well by many theologians. Maybe there is need for the enculturation of some of these processes in the Church. The Church has not been able to satisfy the African Christians' search for healing. The lack of adequate theological knowledge has torn many families apart. It seems to be the reason why some Christians are not fully satisfied with their faith in God and the healing processes in the Church. For this reason, they try to combine them with healing in the traditional way. This suggests a clarion call for the Christian leaders to try and help the families understand how to achieve good health in a systematic and holistic way thereby ensuring the stability of the family. The more holistic healing is achieved among Christian families, the more stable the families are, the healthier the community becomes, and more productivity is achieved in the society.

\section{The Healing Practices in Yoruba Land}

Traditional knowledge of healing is always connected with Traditional Medicine (TM) and healing practices. One who becomes a traditional practitioner or healer must also have an understanding of conventional medicine. Hence, the World Health Organization (WHO, 2013) refers to "traditional medicine as the sum total of information, skills and practices based on the theories, beliefs and experiences original to different cultures that are used to maintain health, as well as to inhibit, diagnose, develop or treat physical and mental diseases" [7].

This definition is a clear indication that the healing practices among the Yoruba are specifically for the human person to regain health that could be lost due to many reasons, for example, through sickness, the vagaries of nature, accidents and so on.

\subsection{Ifa (Divination)}

Every human society has held a belief in at least some form of divination. This is widely celebrated because through divination information can be acquired. Abimbola (2001) a renowned African scholar of Ifa (divination), through his analogy, explains the meaning and the significance of Ifa (divination). According to Abimbola, Ifa, is the divination system created on the odu such as didaowo stories and symbols (divination with the holy divination chain) opele and etite-ale (divination with the religious palm nuts and kolanuts), eerindinlogun (sixteen) [8]. Many reasons motivated the need to do this according to him. One of the motives for consulting Ifa was stressed by Hallen (2000) who specified that educational theorists have excessively communicated their anger beside the recommendation that a mysterious corpus of writings which included fables, folktales, poems, songs as well as the proverbs was honestly worthy of the philosophy [9]. A second reason that was given by the Hallen was that knowledgeable study is that Ifa has a critical status in the oral tradition of Yoruba. Majority of the Ifa writers like E. M Lijalu, William Bascon as well as the Wande Abimbola have offered ethnological deliberations on Ifa. Their analysis provides an image that Ifa is a single social association with only religious, ethnographic, and sociology importance. He cited Abimbola (2004) an Ifa African scholar who recognizes that $I f a$ is a storehouse of Yoruba Philosophy.

Idowu (1962) has asserted the significance of God in Yoruba religion. The Yoruba believe in small deities and other mystical powers. Traditionally, the supporters of If $a$ have belief in Olodumare or Olorun as the Highest One, SelfExisting God [10]. Idowu refers to Olodumare as being supreme across the heaven and earth, and recognized by all as the Head to whom all power belongs and all loyalty is due. The Yoruba accept Olodumare as ultimately the Beginning and the End in their everyday activity of man and woman. He has the definitive excellence over all.

God (Olodumare), has been associated with dominant traits like wholeness, self-existence, superiority, prominence, inexplicableness, harmony, infinity, variety, kindness, compassion, love, authenticity, as well as goodness [11]. The Yoruba faith, or Yoruba religion, is also known as aborisha, or simply Ifa (divination). It is usually viewed as one of the principal components of syncretism, which is identified as the Traditional Religion of Africa. It survived during the slave trade and therefore it is considered in a variety of forms among the Western world, named Aborisha or Esin awon Yoruba (Yoruba Religion). The complexity of the Yoruba cosmology has resulted in Western scholars comparing it to the pantheon of the Ancient Greeks [12].

Among the Yoruba, divination has a lot to do with the Babalawos (initiated priests). They are assumed to be in a position to communicate with the Orunmila in the course of their prophetic ceremonials. Orunmila is the orisa (head guardian) of knowledge, divination, and morals. The Ifa custodians could be referred to as diviners. The diviners are the most significant mediators between individuals and the supernatural, and no individual becomes a diviner by individual choice. In the Yoruba tradition, to be a diviner is mostly a matter of heredity. Diviners deal with identifying the unexplainable. They usually analyse the cause of specific events as well as interpreting communication with the ancestors. They make use of the objects of divination, and they give explanations about the unknown employing their specific powers. In some instances, they can offer treatment 
for the particular condition they have identified. It is good to note that, during 2005, the system of Ifa was included by UNESCO in the list of Masterpieces of the Oral and Intangible Heritage of Humanity" [13].

Awojoodu, et al., (2009), through a comparative approach, explains Ifa (divination) as a power among the Yoruba which is God's angel thought to have been selected to have an endless source of knowledge. These authors narrate the relevance of Ifa to Yoruba people in general. The knowledge of Ifa consists of vegetation, animals, oral chant or ofo (incantation), medicinal tree, and all sciences which deal with the healing [14]. According to the belief of the Yoruba, the Supreme Being provides healing knowledge through the power of Ifa to those who demonstrate themselves praiseworthy [15]. "It is widely agreed that the Yoruba traditionalists are very reluctant or unwilling to start any undertaking without first consulting Orunmila (the oracle god), as known by Ifa" [16]. For Idowu (1996: 5), "Ifa is consulted for the guidance in every situation and the solution to every situation in life, such as, before a betrothal or marriage, at successive stages in a man's life. Before a chief is appointed and in times of crisis or illness, Ifa must be consulted, and this exercise is extended to those seeking for healing". When one is sick and desires to be healed, one consults the Ifa for the cause of the problem and the way forward. The diviner in this situation makes the necessary inquiry and reveals what the oracle says as regards their predicament [17].

To seek for direction through the consultation with Ifa in Yoruba tradition is the final answer to every problem that needs solution. It is believed that the revealed truth must be attended to immediately to avoid further wrath of Olodumare (Almighty God) or Orisa as the case may be. In many cases, people suffer or undergo misfortune for the evil they have committed against their neighbours, and so they are punished by the Orisa. Surprisingly in some situation, once they follow what the oracle says to amend their evil ways and follow the dictates given by the Ifa priest, they are healed instantly. This was demonstrated is a Yoruba film titled: "The wrath of the gods" which was directed by Abeni (2018) [18]. Sometimes, some trees are noted to possess certain supernatural powers. For instance, it is a common belief among the Yoruba that some trees like iroko, ose (baobab tree), araba, arere, peregun and odan manifest and possess some supernatural power. Hence, such trees are deified. In addition, there are more than 401 deities or divinities in Yorùbá land. Òrúnmilà is the custodian of knowledge represented by Ifa (while the Babalawos are the human intermediaries who reveal the Órúnmilà's message to humans) [19].

An Ifa priest with his mystical power has the ability to identify a tree with mystical power as well. Adewale (1988) affirmed that when the Yoruba see signs of the presence of spiritual beings in a tree, for example, or when they observe special features or experience something strange in a particular tree, by demonstrating an unusual manner causing fear and terror to people, they usually consult diviners about the tree [20]. Whatever the oracle says through the Ifa about the tree is believed by the people. They typically perform rituals and sacrifices declared by the diviner from time to time. In the case of one seeking for healing, the sacrifices and offerings offered at that sacred place is believed to bring back health especially when the oracle advised them to act thus [21]. The sacrifices and offerings like palm fronts and pieces of white cloth are tied around the base of such trees. These signs are to warn non-members (ogberi) against trespassing and the risk of misfortune.

The diviners perform divination for different purposes. There has always been the tendency for some greedy diviners to manipulate many innocent people all in the name of what the Ifa oracle demands from them. Sometimes they practice their skills for commercial reasons. Since the diviners are the only ones who can interpret the oracle as a result of the training they have received, whatever they say must be carried out. If this is not done, some consequences follow. They make their profession their job and keep their earnings. Diviners can make huge sums of money out of the people. They determine what a person brings. The upright and Godfearing diviners guide and direct the people by helping them to solve their problems. While the others, who are false diviners, make money from the people. This is because people's desire for healing and the restoration of their health puts the sick in an unsafe situation and so they can be easily exploited. Many who have been victims of such practices have narrated their experiences to family and friends.

Different cases are presented through the Nollywood films. In these, the diviners are paid to say things contrary of what the oracle says. The purpose of this is, either to punish an individual, or for selfish reasons, to which the diviners agreed. Undoubtedly, the truth will come out later, but only after the harm has been done. This is very common among the very wealthy Yoruba people who oppress the poor with their wealth, for example, in the film titled, Igiowo (the tree of wealth) [22]. Some diviners are also healers, and for people in remote areas where there is the absence of professional medical practitioners, these diviners continue to help the sick because of the lack of any other alternative health care-services. As these diviners utilize their knowledge of Ifa for the healing the people, one could doubt if they produce holistic healing in the individual because of the absence of other professionals.

It is important to note that it is not every Christian family that practises Yoruba Traditional Religion simultaneously with Christianity. Wherever there is freedom of religion, it is possible that one who believes firmly in If $a$ oracle can create anxiety for one who does not believe in it. If the problem with a person's health persists, and it seems healing is delayed, the fear of death can make the Christian want to participate in Traditional Religion by visiting the Ifa priest even when he or she does not believe in it. This state of uncertainty can also result in quarrels, disharmony and even lead to separation in the families. Consequently, while many have been helped, the majority have also experienced deep wounds in the quest for healing. 
If $a$ custodians (diviners) are encouraged to use their gifts always to serve humanity positively and not to manipulate people for selfish motives. They must be truthful in identifying correctly what the oracle says and what ought to be done. For those who are healers among them, they are called to be watchful of the sources of the raw materials they use as well as avoiding contaminated materials. In situations where they are unable to solve the problem holistically, they must direct the individual to genuine medical practitioners and professionals outside their circle of healers.

Among the Yoruba, the belief in Ifa is very much alive, and its use is highly recommended mainly by the elders in the community. There is also the fact that though many believe in the power of Ifa it is not highly documented and celebrated. This is attributed to the guidance given by Ifa (divination). Even though many African authors have written and defended belief in Ifa, there is little evidence to support how much this belief has affected Africans especially the Yoruba in attaining holistic health. Hence, this study attempts to find out the effect of these beliefs in achieving holistic health.

Having discussed the relevance of Ifa among the Yoruba, there are also many challenges that need to be noted. The most significant of these challenges is the negative effect it has on the person who thinks everything the Ifa priest says is true and so he or she must perform the rituals and sacrifices prescribed by the Ifa priest. Another challenge that is very common is the fear that is experienced by the person involved. Sometimes, if these challenges are not addressed, they can be a hindrance to the attainment of holistic healing among them especially the Christians.

\subsection{Rituals and Sacrifices}

Generally, when there is illness, people go through a process of healing in various forms to help them to regain their health. Times of sickness are crisis moments in the life of the individual or in the community and the one affected will always seek healing. Sometimes, one of these processes of healing in Africa Traditional Religion involves 'ritual' and 'sacrifice'. The ritual experts with supernatural powers and cultural knowledge are always of great help to the one in need of healing. The ritual practices include prayers, sacrifices, offerings, or all of these. The ritual practices themselves serve as remedies for certain illnesses and in certain situations. The culture in Africa views the human life as spiritual, and besides this view, various aspects of life of the human person go hand in hand with day to day realities. To be able to justify this, Kelly explained the role of rituals and the ancestors in the healing process. According to Kelly (2017), many people do not realize the significance of rituals despite the fact that they practice them [23].

Rituals and sacrifices express transition, dependence, solidarity, social order, and reconciliation. A sacrifice is the act of offering food, objects, or the lives of animals and rarely, human life, for a higher purpose or to gods or God as an act of propitiation or worship [24]. "The African wisdom of healing through rituals enables one to find new balance between the Supreme Being, the community, the environment and the self" [25].

Mbiti, with his vast experience and research among Africans, long ago established that a ritual in the African context is carried out as a religious ceremony or action, which evokes sacredness and intentionality and embodies a belief or beliefs [26]. The African festivals and rituals reveal the religion practised in Africa. For Mbiti, rituals are very effective in Africa because they exercise control over the invisible world and the forces of nature.

Arinze (1970) evaluated the concept of sacrifice in his own culture in Nigeria. His book, entitled "Sacrifice in Igbo Religion", has been reviewed by Shelton (1972) who points out that Arinze's study of Igbo sacrifice shows that sacrifice is the essence of their worship and the heart of their religion [27].

Sacrifice as an ideal and institution is deeply rooted in the thought and practices of the Yoruba. It is the core of worship in the traditional religion of the people. The word for sacrifice among the Yoruba is $e b o$ and the expression $r u$-ebo (to offer sacrifice) is always used in a religious context. Every sacrifice has both positive and negative aspects. In performing any sacrifice, certain things or items are always required from the individual performing the offering [28].

Rituals are always administered by the priests known as aworo or iworo. They are specialists in leading others in worship. They are devotees of the gods (orisa), that is, there is something of the divinity in them and it belongs to their position to offer worship to the orisa. This is because the Yoruba believe strongly that the divinities and ancestors are objects of worship in respect to the God Almighty.

\section{Methodology}

In order to investigate the effects of these healing practices among the Christians in the South West Region of Nigeria, descriptive survey and phenomenology research designs were used in this study. Descriptive survey design is most effective when used in a study that uses questionnaires to collect data and the population is well defined. This method was used to collect data from the Christian families from the five Blocks of the Christian Association of Nigeria (CAN) [29].

The quantitative raw data gathered were edited for accuracy, uniformity, consistency and completeness. There were 70 questions that focused on the demographic data, beliefs, and opinions concerning traditional mystical power beliefs, the source and use of traditional knowledge of healing, traditional healing practices expressed through the practice of Ifa (divination), and beliefs and opinions about rituals and sacrifices. Twenty five of these questions were on the healing practices. The questionnaires were administered to 400 people from four Blocks of Christians in three local government areas in Osun State. This was because one of the blocks, namely, Tarayyar Ekklisiyar Kristi a Nigeria, (the Fellowship of Christian Churches in Nigeria or Evangelical Church Winning All) (TEKAN or ECWA) was not present in the South West Region. ECWA Churches were founded 
specifically in the Northern part of Nigeria, but this study was conducted in the South West Region of Nigeria.

These Christians formed the target population of this study. The three local government areas chosen were Osogbo, Ife Central and Ede North. Furthermore, this design offered the opportunity for the study to cover a wide area using samples that possess the characteristics of the entire population of Yoruba Christians, though there were slight variations according to the different local government areas.

Qualitative data was collected using the phenomenological design method and this was done through interviews. Twenty health care-givers were interviewed as key informants based on the research questions of this study. The central characteristic of this research design is its ability to support the participants' perceptions and experiences on a certain subject matter [30].

The above-mentioned designs ultimately required mixed methods. Hence, qualitative and quantitative data were collected concurrently for the purpose of addressing the problem identified by the researcher, and the results analysed. Later, the coding of data generated from all the informants was completed. Statistical Package for Social Science (SPSS), version 23.0 was then used to analyse the quantitative data [31]. They were later presented as a frequency count and percentages. The qualitative data collected was analyzed by content analysis technique

\section{Results of the Findings}

From the results obtained, it is significant to note that a good number of Christians have commendable attitudes towards religion, while others at various times of their lives have had negative experiences of healing practices. There are two categories of Christians that emerge clearly in this research: $50 \%$ of the Christians affirmed their choice of traditional healing practices when serious health problem arose in the family; the other $50 \%$ did not confirm this but rather stated that they believe in healing through faith in God alone. This could be interpreted to mean that a good number of the practicing Christians make use of traditional healing practices whenever they desire to do so. In some Churches, as presented by some informants, Christians have no problem in making use of traditional medicine, like awon elewe omo (children's healers), or herbal medicine.

The use of leaves especially in the morning was widely encouraged both by some traditional healers, as well as some spiritual healers, who prefer traditional medicines that are indigenous. Surprisingly, in some Churches, while the leaders or pastoral team do not prevent members from using these traditional healers, they are silent about the use of them. The reason for this is still under investigation.

Another crucial point that must be underscored is that many Christians and traditional healers explained that there are stages of healing in both Yoruba Traditional Religion and Christianity. Emphasis was laid on the fact that some things, such as attitudes in the person can hinder healing from taking place. Sin, bad character, negligence, wicked people seeking for revenge are some of these things identified that can hinder or prevent healing from taking place according to traditional expectations. Spiritual healers like priests, pastors and other health care-givers, emphasised the need to create many opportunities for people to attain holistic health in the individual.

For the spiritual healers, God is the 'Great Physician', and all care-givers especially the healers are instruments in the hands of God. In fact, they are sent to participate in the healing work of God, while God does the healing himself. There is a need to have deep faith in God and also to perform the necessary diagnoses that God, through science, has made possible for men and women. Opportunities to use medical facilities have been made available through Government and the Church so that people can have easy access to healing. Having said this, it is important to identify and highlight the two major healing practices that are very common among the Yoruba people.

According to the various traditional healers, there are three clear stages of healing (consultation with Ifa, then divination, and finally the performing of rituals and sacrifices) in a typical Yoruba set up. The results showed that these three stages are related to one another, and that one stage definitely leads to other. The two categories of Christians with their two different perceptions explained their positions independently. Both sides see the Ifa priests and spiritual healers as the Babalawos (healers) of God. In a situation where people think that a sickness or an ailment is caused by the gods who are angry, the cure can only be found by appeasing the anger of the gods. So, the Ifa priest is consulted, and he prescribes the rituals and the sacrifices to be performed and later, gives the remedies. In another situation, one person gives the remedies and another person performs the rituals and sacrifices.

The healers belong to different groups according to their area of specialization and their various talents. One of the discoveries clearly revealed by the research is that some Babalawo or Ifa priests play a double role. It is possible for an Ifa priest also to be a healer. Herbalists who have specialised in specific treatments usually use case histories and traditional herbs to treat the individuals involved [32]. They need to be knowledgeable in witchcraft and this is what distinguishes them from diviners.

For Christians, and in the Catholic Church in particular, the priest who is a spiritual healer, is the same person who offers the sacrifice of the Holy Mass. He celebrates this in thanksgiving to God and for spiritual healing. For those who believe in and consult Ifa from time to time, Ifa is the repository of knowledge. Its wisdom, guidance and information cannot be denied because its efficacy is affirmed. For those Christians who do not participate in Ifa, this way of acting is seen as outmoded, old-fashioned, idolatrous and ineffective, and so should not be celebrated at all.

The research also established the involvement of women in problem-solving in the community and particularly in families. Women are seen as "protector of lives"; "mothers are the ones who in most cases consult diviners for solutions 
to problems. They are the majority of those who, out of love and concern, agree to perform the rituals and sacrifices when the need arises. The singular love and affection of mothers for the families, and their role in nurturing and preserving lives is indispensable. Thus, while Ifa (divination) has an influence on one group of Christians, it has little or no influence on the other group.

Rituals and sacrifices are the second healing practice that is most trusted in Yoruba Traditional Religion (YTR). The research findings indicated that the two groups of Christians held very diverse opinions. Those who believe in the efficacy and usefulness of rituals and sacrifices argued strongly for how trustworthy these can be in solving or minimizing problems in the families. The traditional healers, diviners and the If $a$ priests have a major role to play. For them, rituals and sacrifices are the fastest way to resolve any issue that may destabilise the peace and harmony of the family. Once the ancestors are appeased through rituals and sacrifices, then the problem is resolved.

The other category of Christians who down play the effect of rituals and sacrifices showed that as Christians, they do not understand fully the graces attached to rituals and the sacrifice offered on the Cross for all Christians by Jesus Christ for the forgiveness of sins. This sacrifice on the Cross is the greatest of all sacrifices offered for all Christians that surpasses all the rituals and the sacrifices of animals in African Traditional Religion. Their responses to the questions on rituals and sacrifices betrayed them. The Yoruba Traditional Healers understand this very well and they teach their faithful how to take advantage of it.

The research also showed that majority of the Christians agreed that it is the mother who ordinarily will perform the rituals and sacrifices in the family if need be. Both groups of Christians clearly understood this. The power and the indispensable role of women, especially mothers in protecting and stabilizing the lives of the individual members of their family, particularly in moments of crisis and challenge were clearly understood. This point about the role of women generally in the family was justified by many through the Yoruba movies they watched, while others through testimonies in the Church affirmed this. This brings us to the last finding that emerged from the study.

The effect of Yoruba movies is another strong point that surfaced in the course of this study. From the movies, many Christians come to learn that there are mystical powers in certain people and these can use this power to obstruct the peace and progress of others. Again, through the movies, traditional mystical power is propagated as the main cause of many of the sicknesses and misfortunes happening in families. Though there are elements of truth in this information, it seems there is also much exaggeration in what is portrayed. It is suggested that every solution to health issues or challenges in the family must be solved through consultation with Ifa priests who establish the cause of the problem and prescribe the solution. This study shows that Christian leaders have discredited the wrong and negative ideas portrayed in Yoruba movies, therefore, this wrong mentality needs to be corrected among the Christians. As such, one can conclude that rituals and sacrifices as presented in Yoruba movies influence people in the quest for holistic health among Christian families.

\section{Conclusion}

A good number of practicing Christians utilise traditional healing practices mainly by the use of leaves from time to time. This is usually done when need arises, though there was no clear evidence of the type of healing practices that were used when these became necessary in their families. In some Churches, they do make use of traditional medicine like awon elewe omo (children's healers) or herbal medicine without any problems at all. The wrong notion of what Ifa represents in the mind of the people needs proper attention and reorientation. For the other group of Christians who do not participate in Ifa, this practice is seen as outmoded, oldfashioned, the ineffective worship of idols, and so should not be celebrated at all. Those who believe and consult Ifa from time to time, see Ifa as the repository of knowledge, wisdom, guidance and a source of information. Hence, Ifa (divination) has a great influence on some Christians, while it has little or no influence on other Christians.

Those who believe in the efficacy and usefulness of rituals and sacrifices argued strongly that they can be trusted in solving or reducing problems in the families. Once the ancestors are appeased through rituals and sacrifices, then the problem is resolved. Those Christians who downplay the effect of rituals and sacrifices, do not fully understand the graces attached to the effect of rituals and sacrifices. Hence, there is need for more teaching on the part of the Christian leaders.

The power and the indispensable role of women, especially mothers in protecting and stabilizing the lives of the individual members of their families, particularly in moments of crisis of health and challenges were clearly stated. For this reason, one can categorically say that the genius of women in Yoruba culture was clearly affirmed. Though women and men are equal in God's love, women generally have qualities that can be sanctified in different stages of life. Their gifts and the responsibilities of motherhood, physical or spiritual, are the universal privilege of all women, whatever their status. Yoruba people continue to propagate this to the fullest.

The wrong message spread through Yoruba movies surfaced in the course of this study. They stress that the solution to all health issues or challenges in the family must be found in consultation with Ifa priest who discovers the cause and prescribes the solutions. This needs to be corrected, because it appears that Yoruba movies stress the influence and importance of rituals and sacrifices, and their impact on holistic health among the Christian families.

\section{Recommendations}

1. As a concluding assertion, to achieve holistic health 
among Christians, their leaders must encourage and invest in an on-going formation programme that teaches the inculturation and enculturation of African values. These are the natural and traditional healing practices that involve creativity and God-given talents. The involvement of all health care-givers is indispensable. They must come together as a team in the various Churches to help the spiritual healers achieve the holistic healing that is to be given to the individual members. This is because the human person is not a machine; he is made up of body, mind and soul. And so the healing process in the individual must be an integral not just a mechanical process, one which is both gradual and at the same time perfect and holistic. Christians must be prepared in their minds and their hearts to accept this affirmation so that there will be healthy persons in the society. In this regard, when challenges of health occur in the community, proper steps must be taken and people must avoid looking for a fast solution and the confusion caused by running from pillar to post seeking for magic or miracle. Once proper steps that lead to healing or health have been taken, the rest is left to God who is the perfect healer, the Giver of life, the Protector of life and the One who knows when death will eventually come. All Christians must renew their trust in the Almighty God and Father who is the creator of all that exists in the world.

2. In order to facilitate the preservation of Yoruba medicine and healing practices, there is the need to establish a forum for Yoruba medical practitioners or health caregivers in various Christian communities that will incorporate professionals in all areas of traditional medicine. This association should begin to compile and to document the herbal, traditional Yoruba medicines and their use for all sicknesses. This exercise will correct poor attitudes towards the preservation of Yoruba medicines in the South Region of Nigeria, and allow this knowledge to be shared with others, both those already gifted and those who might be interested in the mission of healing. The Governments of South West Region of Nigeria, in collaboration with the Church leaders, can effectively invest in this great mission of preserving the healing methods and practices among the Christians.

3. To increase faith in and belief in miracles of healing that are being performed daily in the Church, there is need to allocate more time for people to share testimonies concerning the miracles the Lord has performed and what he is doing in their lives in the Church. This will encourage and strengthen those with weaker faith to trust that miracles do happen in the Church and that holistic healing is possible and can be attained. This work should be supported with the provision of healthcare services for those who are in need in various parishes. In this way, holistic health will be given good attention in the Churches. This will counter the wrong notion that Ifa priests are more efficient than the spiritual healers in the Church (the priests and Pastors).
4. In order to control the negative impact of social media, especially its spreading of the erroneous idea that the solution to every problem must come through visiting a herbalist, this study recommends that Christian artists get more involved in film production in South West Region of Nigeria. The suggestion is that all Christian artists, film producers, actors, actresses and film writers of various denominations become involved. Their active participation in the film industry will surely lead to the conveying of positives messages to counter the wrong messages that the people have already propagated. This distorted view of Nigerian films has also affected the impression other Africans have, especially in East Africa, about Nigeria in general. Hence, there is an urgent need to correct this distorted way of thinking through the better use of the media.

5. The importance of rituals and sacrifices cannot be overemphasized, both in Yoruba Traditional Religion and in Christianity. Yoruba people are very aware of the effectiveness of these in YTR and therefore, they are constantly making use of them. On the other hand, there are Christians who need to know that there are also rituals and sacrifices in Christianity. The greatest and the most effective sacrifice was that offered by Jesus Christ once for all by his dying on the Cross, for the remission of our sins. The Christians celebrate this sacrifice daily in memory of Him, especially in the Catholic Church. This celebration keeps the Christian faith alive and active. Therefore, more emphasis needs to be put on teaching Christians the values and the usefulness of sacrifice in their relationship with God, especially when the challenge of sickness or illness occurs in the family. Altogether, there is need for all Christians to move from the level of formation to transformation so that they become authentic witnesses of Christ in the society.

6. Finally, for holistic health to be achievable among Christian families, all must work hard. Families, the Government, all social institutions, the Churches and all health care-givers including traditional healers (those who make use of plants and their God given talents) must work together as a team. This collaborative mission is for the benefit of all. In this way, the challenge presented by the different sicknesses or ailments that may befall anyone in the family can be addressed appropriately. This is the only way to create a favourable environment in which everyone will be helped holistically.

\section{References}

[1] Koenig, HG. (2004). Religion, Spirituality, and health in medically ill hospitalized in older patients. PubMed.gov. Retrieved August 12, 2017, from https://www.hindawl.com.jpurnals.isrn.

[2] Williams, D. (1998). Race, socioeconomic status, and health: The added effects of racism and discrimination. Annals of the New York Academy of Science, 896 (1), 173-188. 
[3] Ng, F. (2007). The interface between religion and psychosis. Australasian Psychiatry, 15 (1), 62-66.

[4] Racine, R. (2014). Loving in the context of community mental health practice: a clinical case study and reflection on mystical experience. Mental Health, Religion \& Culture. 17 (2), 109121.

[5] Aldwin, C. (2014) Religion, Spirituality influence health in different but complementary ways in Oregon State University. Retrieved November, $2017 . \quad$ From http://spiritualityhealth.com/articles/h. Health, 26 (1), spring.

[6] Adodo, A. (2012). Nature Power: A Christian Approach to Herbal Medicine. Nigeria: PAX Herbal Clinic \& Research Laboratories.

[7] Who Media Centre. (2010). Traditional Medicine. Retrieved from September 2017, from http://www.who.int.medicinecentre/factssheets/fc135/en/index .html.

[8] Abimbola, W. (2001). The Bad of Wisdom: Osun and the Origins of Ifa Divination in Osun across the Waters. J. Murphy and M. Sanford (Ed). Indiana: University Press, Bloomington.

[9] Hallen 2000 B. (2000). The Good, the Bad and the Beautiful: Discourse about Values in Yoruba Cultures. Indiana: Indiana University Press. Retrieved from https://philapapers.org/rec/HALTGT-2.

[10] Idowu, B. (1962). Olodumare: God in Yoruba Belief. London: Longmans Publisher.

[11] Mbiti, J. S. (1970). Concept of God in Africa. London: SPCK.

[12] Inform Africa. (2011). Yoruba people of Nigeria, the history, religion, and arts. Retrieved from July 15, 2017, from http://www. informafrica.com/author/informafrica/.

[13] United Nation Educational Scientific and Cultural Organization (UNESCO). (2005). List of the 90 of the Oral UNESCO. Retrieved from https://ich.unesco.org/doc/src/00264-EN.pdf.

[14] Awojoodu, O. \& Baran, D. (2009). Traditional Yoruba Medicine in Nigeria: A Comparative Approach. Bulletin of the Transylvania University of Brasov, Vol. 6 (51). Retrieved from webut.unibv.ro/.../BULETIN2009/SuplimentBU2009/pdf/24 Awojoodu.pdf.

[15] Abimbola, K. (2006). Yoruba Culture: a Philosophical Account. Birmingham: IAP.

[16] Simpson, G. E. (1994). Yoruba Religion and Medicine in Ibadan. Ibadan: Ibadan University Press.

[17] Idowu (1998). Oludumare: God in Yoruba Belief and the Theistic Problem of Evil. African Studies Quarterly, (2) 1. Retrieved from http://www.africa.ufl.edu/asq/v2/v2ila.pdf.
[18] Abeni, A. (2019). Yoruba Nollywood Movies: IBINU ELEYE. Retrieved September 20, 2019, from http://www.you'tube,com/playlist.

[19] Odejobi, C. O. (2014). Influence of Yoruba Culture in Christian Religious Worship. International J. Soc. Sci. \& Education, 4 (3), 2223-4934E and 2227-393XPrint

[20] Adewale, S. (1988). The Religion of the Yoruba: a Phenomenological Analysis. Ibadan. Retrieved May 20, 2019 from https://philpapers.org/rec/ADETRO-2.

[21] Oyemomilara. C. O. (2012). Towards a Contextualization of worship: A challenge to the Nigeria Baptist Convention. ( $\mathrm{Ph}$. D. thesis, University of Manchester). Retrieved October 12, 2017, from https://www.escholar.manchester,ac.uk.

[22] Nollywood Yoruba Movies. (2017). Ibinu Eleye, (Audio podcast) Retrieved from https://www.bing.com/videos/search?q=yoruba=movies=2017.

[23] Kelly, D. D. (2017). The Power of Traditional Healing Methods. The Chopra Centre. Retrieved October 30, 2017, from www.chopra.com/articlew.

[24] Wafula, R. Justificationof Holy Mass as Sacrifice. African Christian Studies, 28 (2), p 44.

[25] Chepkwony, A. K. (Ed), (2006). Religion and Health in Africa, Reflections for the Theology in the 21st Century. Kenya: Pauline's Publications Africa, p. 41.

[26] Mbiti, J. (1975). An African Views: American Black Theology. Worldview, (17) 41-44.

[27] Arinze, F. A. (1970). Sacrifice in Ibo Religion. J. S. Boston, (Ed). Nigeria: Ibadan University Press. Reviewed by Shelton, A. J.

[28] Awolalu, J. O. (2011). "Ifa, the deity of wisdom, and importance of work among the Yoruba people", Journal of Enterprising Communities: People and Places in the Global Economy, 1 (2), pp. 135-141.

[29] Christian Association of Nigeria (2017). Divided People of God: Church Union Movement in Nigeria: Lagos: Nok Publishers Nigeria Ltd., pp. 16-23.

[30] Tanur J. (Ed.). (1992). Questions about questions. Inquiries into the cognitive bases of surveys. New York: Russell Sage Foundation.

[31] Saris, W. \& Gallhoffer, I. (2014). Design, Evaluation, and Analysis of Questionnaires for Survey Research (2nd Edition). New Jersey: John Wiley \& Sons, Inc.

[32] Odebiyi, A. I. (1989). Food Taboos in Maternal and Child Health: the Views of Traditional Healers in Ile-Ife, Nigeria. Soc. Sci. Med. 28 (9): 985-996. 